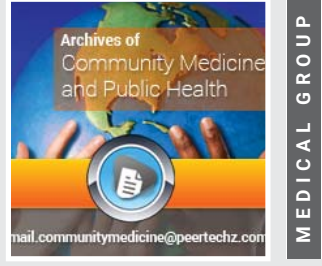

\title{
How COVID-19 has affected the marine sector?
}

\section{Devran Yazir*}

Surmene Faculty of Maritime Sciences, Karadeniz Technical University, Surmene, Trabzon, Turkey

Received: 13 May, 2021

Accepted: 24 May, 2021

Published: 25 May, 2021

*Corresponding author: Dr. Devran Yazir, Surmene Faculty of Maritime Sciences, Karadeniz Technical University, Surmene, Trabzon, Turkey,

E-mail: dyazir@ktu.edu.tr

https://www. peertechzpublications.com
The coronavirus (Covid-19), which has affected the whole world, has caused great problems to countries economically and sociologically. In this process, while many workplaces have had to stop their activities due to Covid-19, some sectors continued their activities. The closure of land borders and airlines led to more active use of the sea route. Therefore, the most important transportation sector has been the maritime sector.

Also, the marine sector has become the most preferred sector in the Covid-19 process, as it is safer than transportation by land and air sectors in international trade [1]. This situation once again revealed how effective the marine industry is on humanity.

Covid-19 has become a global pandemic, perhaps the worst global crisis ever. Also, Covid-19 has shown its effects in more than one area, including health, education, production, world trade and international agreements. National and international measures have been taken and continue to be taken to reduce the impact of the pandemic. Due to these strict measures, the global economy was adversely affected. Industrial production and energy use have decreased by up to $30 \%$ in just a few weeks, as many countries have taken strict measures to protect public health [2]. Since maritime transport carries about 80 per cent of global trade, attention should be paid to maritime transport so that international trade can continue [3]. So, it is important to operate commercial ships in a safe, fast, and most efficient way.

The measures taken due to the pandemic have also revealed some problems in sea transportation. Some of these can be listed as follows;

- Inability to do or postpone internships to be made as a requirement of marine education,

- Late execution of routine operational activities,
- Failure to change the ship's crew in time,

- Delays in the repair and maintenance of ships,

- Problems encountered during the survey and inspection of ships,

The problems experienced in the purchase of fuel, freshwater, food, and drinks to be taken on board can be briefly mentioned.

In addition to the problems mentioned above, the effect of COVID-19 on the ship's crew is an undeniable fact. Thus, the following parameters should be considered [4].

These are;

During the quarantine period, extra precautions should be taken to ensure that the crew is kept under surveillance for 14 days during the embarkation and disembarkation of the ship,

To minimize the effects of the Covid-19 virus on a ship's crew, it should be taken forward to be vaccinated around the world,

As it may prevent the crew from joining the ship due to the travel restriction, it will cause the people working on the ship at that time to make long-term contracts. To prevent this situation from causing psychological problems in the crew of the ship, psychological counsellors should be actively kept on hold by agency and companies,

On the other hand, the crew of the ship who cannot get on the ship may experience problems economically and problems in family order may be encountered. To avoid these situations, countries should provide economic support to them,

Finally, International Maritime Organization (IMO) and similar organizations should continue to advise countries so that ship employees, agencies and companies are minimally 
affected by all these situations. In addition, definitive solutions and measures should continue to be taken throughout the world to provide a more flexible environment with each passing day to keep the ports open, change the ship's crew and prevent the ship's crew from experiencing health problems.

If the flexible working environment is not maintained during COVID-19, several disputes may arise between charterers and owners over the duration of charter, laytime and discussions of clauses. As a result of conflicts, many people may be unemployed [5]. In additionally, several small companies involved in the marine industry during the pandemic period has begun to experience bankruptcies, like companies serving the land sector. The most obvious effects of bankruptcy are the decrease in the demand for cargo, the incapability of companies to find sufficient financial support and the problems experienced in the company management [5].

As the effect of the pandemic continues around the world, many governments have imposed national and international restrictions. For this reason, the jobs of companies, agencies, interns, and other ship crews are getting harder. Therefore, several precautions should be taken. These are respectively:

- Periodic tests should be carried out for the ship's crew within the ship,
- Following the STCW rules, the interns have to do an internship on the ship. However, due to COVID-19, the internship process is getting longer or cancelled. For this reason, companies should allocate extra quotas for students who will start their internship.

\section{Acknowledgment}

The author would like to thank Yusuf TEKEL for providing with constructive comments and suggestions to improve this manuscript.

\section{References}

1. Kuzu AC (2020) COVID-19 ile birlikte denizcilik nereye evrilecek? Marine Deal News. Link: https://bit.ly/3yljlpN

2. Yazir D, Sahin B, Yip TL, Tsen PH (2021) Effects of COVID-19 on maritime industry: a review. Int Marit Health 71: 253-264. Link: https://bit.ly/3wv5K8w

3. United Nations Conference on Trade and Development (2020) Review of Maritime Transport United Nations Conference on Trade and Development. Link: https://bit.ly/3ufvcxi

4. Leptos-Bourgi S (2020) Shipping industry responding to COVID-19 - Keeping the lights on with a response strategy plan. Link: https://pwc.to/3hP91eT

5. Firm S (2020) Impact of COVID-19 on the shipping and maritime industry United Arab Emirates. Link: https://bit.ly/3wwx2f0
Discover a bigger Impact and Visibility of your article publication with

Peertechz Publications

Copyright: (c) 2021 Yazir D. This is an open-access article distributed under the terms of the Creative Commons Attribution License, which permits unrestricted use, distribution, and reproduction in any medium, provided the original author and source are credited. 